\title{
Ectopic Expression of the Erythrocyte Band 3 Anion Exchange Protein, Using a New Avian Retrovirus Vector
}

\author{
S. FUERSTENBERG,${ }^{1}$ H. BEUG,${ }^{2}$ M. INTRONA,${ }^{3}$ K. KHAZAIE,${ }^{4}$ A. MUÑOZ, ${ }^{5}$ S. NESS, ${ }^{6}$ K. NORDSTRÖM, ${ }^{1}$ \\ J. SAP, ${ }^{7}$ I. STANLEY,${ }^{8}$ M. ZENKE, ${ }^{2}$ AND B. VENNSTRÖM ${ }^{1 *}$ \\ Department of Molecular Biology, CMB, Karolinska Institute, Box 60400, S-10401 Stockholm, Sweden ; Research \\ Institute of Molecular Pathology, A-1030 Vienna, Austria ${ }^{2}$; Department of Molecular Biology “Borgomainero,"' Instituto \\ Richerche Farmacologiche "Mario Negri," I-20157 Milano, Italy3 ; Deutsches Krebsforchungszentrum, Institut für \\ Immunologie und Genetik, ${ }^{4}$ and European Molecular Biology Laboratory, Differentiation Programme, ${ }^{6}$ D6900 Heidelberg, \\ Federal Republic of Germany; Instituto de Investigaciones Biomedicas, c/Arturo Duperier 4, E-28629 Madrid, Spain ${ }^{5}$; \\ Department of Chemical Immunology, Weizman Institute of Science, I-76150 Rehovot, Israel ${ }^{7}$; and Ludwig \\ Institute for Cancer Research, Royal Melbourne Hospital, Victoria 3050, Australia
}

Received 24 April 1990/Accepted 4 September 1990

\begin{abstract}
A retrovirus vector was constructed from the genome of avian erythroblastosis virus ES4. The v-erbA sequences of avian erythroblastosis virus were replaced by those coding for neomycin phosphotransferase, creating a gag-neo fusion protein which provides $\mathbf{G 4 1 8}$ resistance as a selectable marker. The v-erbB sequences following the splice acceptor were replaced by a cloning linker allowing insertion of foreign genes. The vector has been tested in conjunction with several helper viruses for the transmission of G418 resistance, titer, stability, transcription, and the transduction and expression of foreign genes in both chicken embryo fibroblasts and the QT6 quail cell line. The results show that the vector is capable of producing high titers of $\mathbf{N e o}^{\mathrm{r}}$ virus from stably integrated proviruses. These proviruses express a balanced ratio of genome length to spliced transcripts which are efficiently translated into protein. Using the Escherichia coli $\beta$-galactosidase gene cloned into the vector as a test construct, expression of enzyme activity could be detected in 90 to $95 \%$ of transfected target cells and in 80 to $85 \%$ of subsequently infected cells. In addition, a cDNA encoding the avian erythrocyte band 3 anion exchange protein has been expressed from the vector in both chicken embryo fibroblasts and QT6 cells and appears to function as an active, plasma membrane-based anion transporter. The ectopic expression of band 3 protein provides a visual marker for vector function in these cells.
\end{abstract}

Recombinant retroviruses have proven to be a highly efficient means of delivering foreign genes into cultured cells $(12,41,42)$ or organisms $(31,52)$. The most widely used systems employ replication defective murine leukemia virusbased vectors and complementing packaging cell lines which allow transcapsidation of vector RNAs into viral particles for infecting most types of mammalian cells $(9,17,63)$. In the avian system, replication-defective retrovirus vectors have mainly been constructed for specific experimental purposes $(18,43,53)$, though some have been adapted for general use $(6,16)$. Replication-competent vectors based on Rous sarcoma virus (RSV; 29, 55) have been constructed with the viral src sequence replaced by a cloning site for cDNAs. These vectors, however, have a limited cloning capacity, making them unsuitable for the insertion of a selectable marker plus a gene of interest. Finally, three packaging cell lines that are based on avian leukosis virus and that provide the functions required in trans for the encapsidation of defective recombinant vector-derived RNAs have been reported $(13,56,60)$. All harbor Rous-associated virus type 1 (RAV-1) proviruses, with partial deletions in the packaging $(\psi)$ sequences. Though other modifications to the RAV-1 genome were made, in two of these lines $(56,60)$ clones which produced high titers of virus also released replicationcompetent helper virus as a result of recombination. The other packaging line (13) was created by separating helper functions on two independent plasmids, reducing the risk of recombinant helper virus production.

\footnotetext{
* Corresponding author.
}

We report here the development of a flexible avian erythroblastosis virus ES4 (AEV-ES4)-based vector which contains all of the sequences known to be required for packaging of viral RNAs (11), a selectable marker (neo), and a large cloning capacity. The vector is capable of sustained production of high titers of recombinant virus and stable, efficient expression of cloned sequences when transfected into chicken embryo fibroblast (CEF) or QT6 cells. It can be used in conjunction with several of the avian leukosis virus helper viruses or packaging cell lines.

We have used the Escherichia coli lacZ ( $\beta-\mathrm{Gal})$ gene cloned into the vector pSFCV to test parameters such as transduction and expression of cloned sequences. We have shown that the recombinant $\beta-G a l$ gene-carrying proviruses efficiently express $\beta-\mathrm{Gal}$ activity in up to $95 \%$ of transfected target cells and in up to $85 \%$ of infected target cells.

In addition, a eucaryotic cDNA has been inserted to test the vector. This cDNA encodes the chicken band 3 anion transport protein, which catalyzes the exchange of $\mathrm{HCO}_{3}{ }^{-}$ and $\mathrm{Cl}^{-}$at the erythrocyte plasma membrane and also functions as an anchor for the erythroid cytoskeleton. In the chicken, band 3 protein is encoded by two distinct polypeptides (30) generated by alternative initiation and splicing (34, 35 ). The band 3 protein transduced by our vector produces only one of these polypeptides yet appears to function as an active ion transporter correctly situated in the plasma membrane of these cells.

\section{MATERIALS AND METHODS}

Cells and culture. CEF were prepared from 11-day-old SPAFAS embryos (Lohmann GmbH, Cuxhaven, Federal 

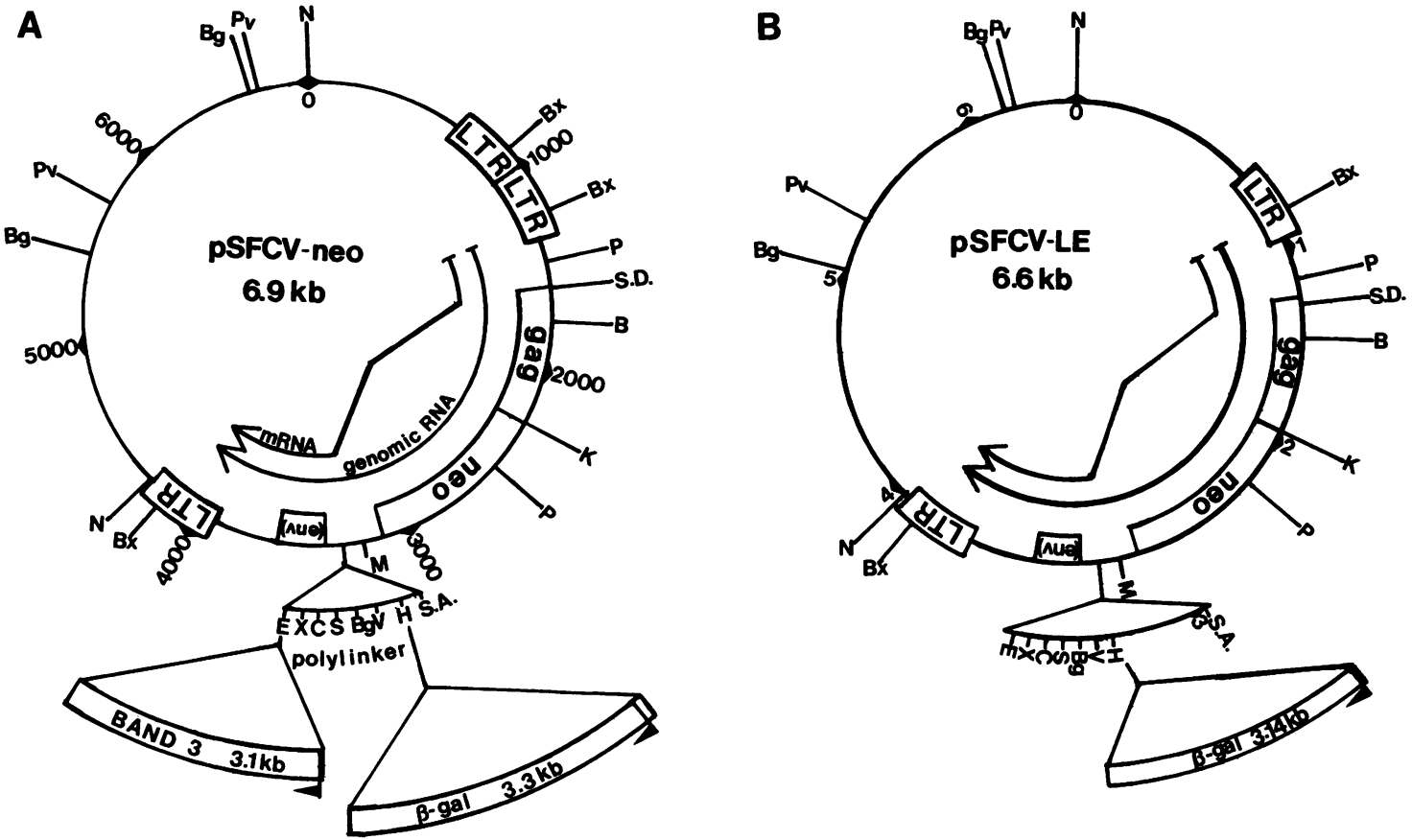

FIG. 1. Schematic representation of pSFCV-neo and pSFCV-LE vectors, showing the location of rare or unique restriction sites, nucleotide numbers (marked every $1,000 \mathrm{bp}$ ), locations of predicted genomic and subgenomic RNAs, location of retroviral sequences, the gag-neo fusion protein coding sequence (G418 resistance), splice donor and acceptor sites, and cloning polylinker. (A) pSFCV-neo, a 6,883-nt vector into which the band 3 protein coding sequence has been introduced. pSFCV-BIIIR is a 3.1-kb band 3 protein cDNA inserted into the $E c o R I$ site of pSFCV-neo. pSFCV-BIIIW is the same sequence cloned in the opposite orientation. The 3.3-kb $\beta$-Gal gene was cloned into pSFCV-neo at the HindIII site in the construct pSFCV- $\beta$. (B) Modified vector pSFCV-LE with a single 5' LTR and an 88-bp oligonucleotide inserted between the splice acceptor and polylinker. The vector pSFCV-LE containing a 3.14-kb $\beta$-Gal insert at the HindIII site is the plasmid pSFCV-Blue. S.A., splice acceptor; S.D., splice donor; B, BamHI; Bg, BglI; Bx, BstXI; C, ClaI; H, HindIII; K, KpnI; M, BsmI; N, NotI; P, PstI; Pv, PvuI; S, SfII; V, EcoRV; X, XbaI. The arrows on the inserts show the location of AUG and the direction of transcription.

Republic of Germany) as previously described (23). Both CEF and quail QT6 (44) cells were grown in Dulbecco modified Eagle medium supplemented with $4 \%$ fetal calf serum, $2 \%$ chicken serum, and $10 \mathrm{mM}$ HEPES $(N$-2-hydroxyethylpiperazine- $N^{\prime}$-2-ethanesulfonic acid; $\mathrm{pH}$ 7.3). Selection for $\mathrm{Neo}^{\mathrm{r}}$ cells was done in medium containing $0.8 \mathrm{mg}$ of G418 (Geneticin; Sigma Chemical Co.) per $\mathrm{ml}(\mathrm{wt} / \mathrm{vol})$ for CEF and $1.0 \mathrm{mg} / \mathrm{ml}$ for QT6 cells. The Q2 and Q4 packaging cell lines were maintained as described elsewhere (60) and otherwise treated as described for QT6 cells. The Isolde packaging line was maintained as recommended elsewhere (13) and otherwise treated as described for QT6 cells.

Vector construction. pSFCV-neo (Fig. 1A) was constructed from AEV clones 10 and $11(14,21,64,66)$, representing unintegrated circular viral DNA, and inserted into plasmid pUC19 by standard methods (40). The pUC19 polylinker was removed and replaced with NotI linkers. AEV-derived fragments were then cloned into the plasmid NotI site, and the vector was constructed with the sequences outlined in Table 1. pSFCV-LE was constructed from pSFCV-neo by a partial Bst XI digestion and religation to create a single, fused, upstream long terminal repeat (LTR). In addition, an 88-bp spacer sequence derived from the human epidermal growth factor (EGF) receptor (nucleotides [nt] 105 to 186) was inserted into the HindIII site of the polylinker, destroying the upstream site but retaining the downstream site (Fig. 1B).

DNA transfection and virus production. Transfections were performed by the method of Graham and Van der Eb as modified by Chen and Okayama $(10,24)$. Vector DNA was cotransfected with RAV-1, RAV-2, or RCAN-BHpol (28, 47, 62) helper virus DNA in a 10:1 $\mu \mathrm{g}$ (vector/helper) ratio. Selection for G418-resistant $\left(\mathrm{Neo}^{\mathrm{r}}\right.$ ) cells was initiated $48 \mathrm{~h}$ after transfection by splitting the cells ( 1 to 3 for CEF, 1 to 10 for QT6) into G418-containing medium. Following selection of $\mathrm{Neo}^{\mathrm{r}}$ cells ( $\sim 6$ days), cultures were maintained in normal medium. Stable clones of $\mathrm{Neo}^{\mathrm{r}}$ QT6 cells producing virus were made by isolation and expansion of individual colonies following G418 selection. Virus stocks were prepared by withdrawal of $\mathrm{G} 418$ from the medium $24 \mathrm{~h}$ prior to collection of cell culture supernatants from $10-\mathrm{cm}$ plates. The media supernatants were filtered through $0.45-\mu \mathrm{m}$-poresize filters (Schleicher \& Schuell, Inc.) and frozen at $-70^{\circ} \mathrm{C}$. The Q2, Q4, and Isolde packaging cell lines were transfected according to the method of Graham and Van der Eb (24), and G418 selection and harvest of virus were done according to the procedure described above for QT6 cells.

Virus infection and titration of virus. Cells $\left(10^{6}\right)$ were infected with 1 to $5 \mathrm{ml}$ of culture supernatants containing 8 $\mu \mathrm{g}$ of Polybrene (Sigma) per $\mathrm{ml}$ for 1 to $2 \mathrm{~h}$. Normal medium was added, and the cells were grown for a further $48 \mathrm{~h}$ and split into medium containing G418. The medium with G418 was changed every 2 days until selection was complete, and the Neo ${ }^{r}$ cultures were expanded for preparation of RNA, DNA, and protein. Titration of virus produced by transfected or infected pools or clones of cells was done by infection of $5 \times 10^{5}$ CEF or $10^{5}$ QT6 cells on duplicate 60-mm dishes with $0.5 \mathrm{ml}$ of serial virus dilutions in medium containing $8 \mu \mathrm{g}$ of Polybrene per $\mathrm{ml}$. The infections were done at room temperature for $15 \mathrm{~min}$ on a rocking platform. 
TABLE 1. Location of important features in pSFCV-neo ${ }^{a}$

\begin{tabular}{lll}
\hline Nucleotide no. & \multicolumn{1}{c}{ Site $^{b}$} & Source (reference) \\
\hline 6683 & Former EcoRI site of pUC19 & \\
$1-8$ & NotI linker & \\
9 & Beginning of AEV sequences & pAEV-11 $(18,59)$ \\
$643-1320$ & 5' double LTR & pAEV-11 $(18,59)$ \\
$982-983$ & Circle junction & pAEV-11 $(18,59)$ \\
$983-1210$ & $5^{\prime}$ U3 (promoter) & pAEV-11 $(18,59)$ \\
$1220-1240$ & R & pAEV-11 $(18,59)$ \\
$1241-1320$ & 5' U5 & pAEV-11 $(18,59)$ \\
1220 & Cap site & pAEV-11 $(18,59)$ \\
$1321-1335$ & tRNA primer binding site & pAEV-11 $(18,59)$ \\
1597 & gag-neo initiation codon & pAEV-11 $(18,59)$ \\
$1597-2243$ & gag coding sequence & pAEV-11 $(18,59)$ \\
$2244-2285$ & Synthetic oligo & \\
$2251-3043$ & neo coding sequence & Tn5 \\
1614 & Splice donor site & pAEV-11 \\
$3043-3291$ & erbB intron & pAEV-11 \\
3291 & Splice acceptor site (v-erbB) & pAEV-11 \\
$3302-3370$ & Cloning polylinker & Synthetic oligo \\
3320 & Stop codon (spliced mRNA) & Synthetic oligo \\
$3303-3356$ & Cloning sites & Synthetic oligo \\
$3357,3362,3366$ & Stop codons (all frames) & Synthetic oligo \\
$3369-3603$ & AEV env (noncoding) & pAEV-10 $(18,59)$ \\
$3604-3896$ & AEV 3' noncoding region & pAEV-10 $(18,59)$ \\
$3897-4135$ & 3' U3 & pAEV-10 $(18,59)$ \\
$4135-4155$ & R & pAEV-10 (18, 59) \\
$4156-4235$ & 3' U5 & pAEV-10 (18, 59) \\
$4129-4134$ & Polyadenylation signal & pAEV-10 (18, 59) \\
4156 & Polyadenylation site & pAEV-10 $(18,59)$ \\
4242 & End of AEV sequence & pAEV-10 $(18,59)$ \\
$4243-4251$ & NotI linker & \\
4252 & Former HindIII site of pUC19 & \\
\hline
\end{tabular}

${ }^{a}$ Details of the construction and compiled sequence of pSFCV-neo can be obtained upon request over computer network (BVE@Kitomo.KI.SE) or by sending an address-labeled Macintosh-formatted diskette. Sequences derived from AEV-ES4 are present at nt 1 to $\mathbf{4 2 4 2}$ and make up the retroviral segment, including the bacterial neomycin phosphotransferase gene and a 68-bp synthetic cloning linker following the splice acceptor. All cloned sequences are intended to be expressed from the spliced subgenomic transcript, must supply their own AUG, and are cloned in the same orientation as viral sequences. The selective marker, G418 resistance, is provided by a gag-neo fusion protein. A synthetic linker joins the two reading frames to create the p558ag-neo hybrid protein. Nt 4243 to 6683 represent the pUC19 plasmid backbone. In pSFCV-LE, modifications which leave a single 5' LTR and extend the distance from the splice acceptor to the cloning linker have been introduced.

${ }^{b} \mathrm{U} 3$, U5, R, Unique $3^{\prime}, 5^{\prime}$, and repeated sequences of the LTR, respectively; env, retroviral envelope gene.

Five milliliters of normal medium was then added, and the cells were returned to the incubator. The cells were washed and refed with fresh medium $24 \mathrm{~h}$ later and refed with medium containing G418 $48 \mathrm{~h}$ after the time of infection. Thereafter, the selective medium was changed every day until easily visible $\mathrm{Neo}^{\mathrm{r}}$ colonies appeared ( $\sim 12$ days), at which time the cells were fixed in methanol-acetone (2:1) and stained with gentian violet to count colonies. Only colonies of average size or larger were counted as resulting from the initial virus infection; they were used to calculate titers as infectious $\mathrm{Neo}^{\mathrm{r}}$ units per milliliter.

Supernatants from the Q2 and Q4 packaging lines were assayed for titer on QT6 cells as described above. Virus production by Isolde lines were similarly assayed for titer on CEF cells or by dot blot (see below). To test for the production of replication-competent recombinant helper virus, fresh QT6 cells were infected with culture supernatants from SFCV-neo-transfected Q2 or Q4 cells, or CEF cells were infected with culture supernatants from SFCV-Bluetransfected Isolde cells and then selected for outgrowth of
G418-resistant colonies. The G418 was withdrawn from the medium, and the culture supernatants were once again harvested to infect fresh QT6 or CEF cells, which were selected on $\mathrm{G} 418$ for outgrowth of resistant colonies. Any $\mathrm{Neo}^{\mathrm{r}}$ colonies appearing in this final infection were assumed to be due to recombination of the input SFCV-neo or SFCV-Blue vector sequences with the resident RAV-1 genome of the Q2, Q4, or Isolde packaging line.

Estimation of virus titer by using RNA dot blot. Virus titers from cells harboring SFCV-Blue constructs were estimated by dot blot hybridization. Virus was pelleted from supernatants of SFCV-Blue-transfected Isolde clones or from helper virus-cotransfected CEF pools and used to prepare RNA for dot blotting as previously described (33). Serial threefold dilutions of RNA were applied to nitrocellulose by using a dot blot manifold (40) and hybridized by using a ${ }^{32}$ P-labeled 910-bp neo probe. Conventionally assayed SFCV-Blue supernatants (see Virus infection and titration of virus above) were used as controls for comparative estimation of virus titers by scanning the autoradiograph with an integrating laser densitometer. These values were converted to estimated virus titer, expressed as units ${ }^{\mathrm{e}}$ per $\mathrm{ml}$ (see Table 3).

Southern and Northern (RNA) analyses. Genomic DNA was prepared from $10-\mathrm{cm}$ plates of confluent cells, digested with BstXI or BglII, subjected to electrophoresis on $0.8 \%$ agarose gels, and transferred to nylon membranes (Hybond $\mathrm{N}$; Amersham Corp.). Southern blots were probed with a ${ }^{32}$ P-labeled neo fragment prepared by random hexamer labeling (19) (Multiprime Labeling System; Amersham). $\operatorname{Poly}(\mathrm{A})^{+}$RNA for Northern analysis was prepared as previously described $(65)$ from $15-\mathrm{cm}$ plates of semiconfluent cells. Poly(A) ${ }^{+}$RNA (1 to $2 \mu \mathrm{g}$ ) was electrophoretically separated on $1 \%$ agarose-formaldehyde gels containing MOPS (morpholinepropanesulfonic acid, pH 7.0) at $140 \mathrm{~V}$ for 4 to $5 \mathrm{~h}$. The RNA was transferred to membranes and hybridized with ${ }^{32} \mathrm{P}$-labeled neo, env, or chicken band 3 protein fragments derived from pSFCV-BIIIR.

$\beta-G a l$ assays. In situ assays for $\beta-G a l$ production were performed on glutaraldehyde-fixed subconfluent plates of SFCV-Blue-transfected or infected CEF or Isolde cells according to a protocol described by Dannenberg $(15,50)$. Blue colonies were counted after 6 to $10 \mathrm{~h}$. To determine the percentage of colonies expressing $\beta-\mathrm{Gal}$, these plates were rinsed in phosphate-buffered saline, treated with acetonemethanol, and stained with gentian violet to assess the total number of $\mathrm{Neo}^{\mathrm{r}}$ colonies. Only blue colonies of uniform size $(\beta-\mathrm{Gal})$ were scored.

Protein analyses. Immunoprecipitation of ${ }^{35} \mathrm{~S}$-labeled cell extracts with gag and band 3 protein antibodies was done as previously described (3), using protein A-Sepharose (Pharmacia) and monoclonal antibodies MCA2E (67) to chicken band 3 protein, MC4.2. A5 (25) to chicken hemoglobin, and M3CZC (26) to viral gag (p19) polypeptides. Labeled extract $\left(10^{7} \mathrm{cpm}\right)$ was used for each immunoprecipitation.

For immunofluorescence studies, fibroblasts were detached from the culture plastic with EDTA and fixed in paraformaldehyde. Anti-chicken band 3 protein monoclonal antibody coupled to fluoroscein isothiocyanate-goat antimouse immunoglobulin was used to visualize the location of the band 3 protein, as described elsewhere (68).

Assay for anion transporter function. Anion transporter activity was tested in two ways. First, SFCV-BIIIR- and SFCV-BIIIW-infected ( $\mathrm{Neo}^{r}$ ) cells were cultured for $24 \mathrm{~h}$ in the presence or absence of $0.4 \mathrm{mM}$ DIDS (diisothiocyanodihydrostilbene-2.2' disulfonic acid; Sigma), a specific inhibitor of band 3 protein activity. The presence of vacuoles was 
monitored under a phase-contrast microscope. Second, cells infected with SFCV-BIIIR or SFCV-BIIIW were grown in parallel in normal media adjusted to $\mathrm{pH} 7.2$ or 8.0 by the addition of bicarbonate and allowed to grow for $48 \mathrm{~h}$. The presence of vacuoles was monitored under the microscope.

\section{RESULTS}

Strategy for pSFCV-neo vector construction. We chose the AEV-ES4 genome as the basis for the construction of pSFCV-neo, since the AEV LTRs are active in many types of avian cells, including fibroblasts, erythroblasts, myeloblasts, and blastoderm cells $(4,20,22)$. Also, the virus is efficiently packaged when pseudotyped with a variety of helper viruses, yielding titers of $10^{5}$ to $10^{6}$ infectious particles per $\mathrm{ml}(20,22)$. In pSFCV-neo, the LTRs and gag sequences originate from the cloned AEV genome (66; Fig. 1). Because packaging sequences, a splice donor site, and other functions (11) are in part located in the gag regions of avian sarcoma and leukosis viruses, we chose to retain 646 nucleotides of gag coding sequence (NaeI site). To be able to accommodate a selectable marker $\left(\mathrm{Neo}^{r}\right)$ as well as one or several additional genes in the vector genome, we fused the necessary parts of gag in frame with the bacterial neomycin phosphotransferase gene (neo). In this way, transcription, packaging, and selectable marker functions were confined to a minimal genetic unit. The gag-neo hybrid protein has an estimated molecular size of 53,000 daltons and is expressed from genome-length RNA at easily detectable levels.

The $\mathrm{Neo}^{\mathrm{r}}$ gene is followed in pSFCV-neo by a short intervening sequence and a splice acceptor site, both derived from AEV. In spliced subgenomic RNAs from avian retroviruses, the splice donor site is preceded by the six initial codons of gag. To allow the expression of unmodified proteins from subgenomic mRNAs, we inserted after the splice acceptor site a polylinker containing a terminator codon in frame with the upstream AUG. Consequently, cloned sequences had to supply their own start codon. The restriction sites in the polylinker are followed by stop codons in all three reading frames, and mRNAs utilize polyadenylation signals in the $3^{\prime}$ LTR. The HindIII site at the start of the polylinker and the EcoRI site at the end facilitate the insertion of genes from pUC vectors. The ClaI site in the SFCV-neo polylinker allows the insertion of an additional gene by the use of adaptor plasmids (28), which carry their own splice acceptor site, initiator AUG, and cloning polylinker. All polylinker sites except that for $B g l \mathrm{I}$, which is also present in the plasmid vector, are unique in pSFCV-neo. The $B s t$ XI sites in the LTRs are unique and can be used to excise the integrated provirus. NotI linkers separate SFCV sequences from the pUC backbone in the plasmid pSFCV-neo. The genomic transcript has a calculated length of 2,963 nt, and the spliced mRNA is $1,250 \mathrm{nt}$, excluding the insert and poly(A) tail. The estimated cloning capacity based on RSVderived vectors $(48,58)$ is greater than $6.5 \mathrm{~kb}$.

pSFCV-BIIIR (band 3, Fig. 1A) represents the vector pSFCV-neo containing an EcoRI insert of $3.1 \mathrm{~kb}$ containing the cDNA for the avian erythrocyte band 3 protein (68) in the same orientation as the viral sequences. The insert harbors its own ATG initiating codon and stop codons. This particular construct was designed to express band 3 protein as a spliced viral transcript via the promoter and polyadenylation site in the retroviral LTRs. pSFCV-BIIIW contains the same EcoRI fragment in the opposite orientation.

pSFCV- $\beta$ ( $\beta$-gal, Fig. 1A) contains $3.3 \mathrm{~kb}$ of bacterial $\beta-G a l$ sequence cloned at the HindIII site of the SFCV-neo polylinker. The expression of the spliced $\beta-G a l$ mRNA from SFCV- $\beta$ was easily detectable by Northern analysis (data not shown), but transfected cells scored weakly or unevenly positive when in situ assays were used to determine $\beta-\mathrm{Gal}$ activity. Since the construct produced only weak enzyme activity, it was used for quantitation of virus production and Southern blot analysis only.

pSFCV-LE (Fig. 1B) was constructed from pSFCV-neo by partial BstXI digestion and religation to create a single upstream LTR. In addition, a modification was made to ensure the efficient translation of inserted sequences. In pSFCV-neo, the presence of a stop codon following the splice acceptor prevents the fusion of gag sequences to cloned genes. To provide a proper distance (37) between this stop codon and the AUG of cloned sequences, we inserted a synthetic 88-bp fragment representing a modified form of the human EGF receptor 5' untranslated region (nt 105 to 186) into the HindIII site of the pSFCV-neo polylinker. This version of the vector efficiently allowed production of $\beta-G a l$ (assayed in situ for enzyme activity) as a HindIII insert in pSFCV-LE.

pSFCV-Blue ( $\beta$-gal, Fig. 1B) represents a 3.14-kb E. coli $\beta-G a l$ (50) fragment cloned into the HindIII site of pSFCV-LE in the same orientation as viral sequences. This construct was used for in situ quantitation of $\beta$-Gal activity and virus production (Tables 2 and 3 ).

Expression of neomycin resistance by SFCV-neo. To test the ability of SFCV-derived gag-neo hybrid protein to provide $\mathrm{G} 418$ resistance to CEF and QT6 cells, pSFCV-neo was compared with the plasmid pSV2neo (45) in parallel transfections. Equal amounts of plasmids were transfected onto CEF cells, and the resulting sizes and numbers of $\mathrm{Neo}^{\mathrm{r}}$ colonies were noted. pSFCV-neo gave between 50 and 70 , pSFCV- $\beta$ gave 80 to 100 , and pSFCV-Blue gave 90 to 100 $\mathrm{Neo}^{r}$ colonies per $\mu \mathrm{g}$ of DNA, comparable with that observed using pSV2neo ( 25 to $30 \mathrm{Neo}^{r}$ colonies per $\mu \mathrm{g}$ ) at 0.8 $\mathrm{mg}$ of $\mathrm{G} 418$ per $\mathrm{ml}$. At G418 concentrations of $2.0 \mathrm{mg} / \mathrm{ml}$, all plasmids gave 10 to $15 \mathrm{Neo}^{r}$ colonies per $\mu \mathrm{g}$ of DNA. The size of the $\mathrm{Neo}^{\mathrm{r}}$ colonies from SFCV transfectants were comparable with those of pSV2neo transfectants.

Virus production by pSFCV-neo-helper-transfected cells. To estimate the amount of virus released by cells harboring the SFCV-neo provirus, constructs were cotransfected into CEF or QT6 cells with several helper virus DNAs such as RAV-1, RAV-2, and RCAN-BHpol. RCAN-BHpol is a construct based on RSV-Schmidt-Ruppin A, which lacks $\mathrm{v}-s r c$, contains the pol region of the Bryan high-titer strain (RSV), and was designed to produce higher titers of virus $(28,47,62)$. Culture supernatants were harvested from pools of CEF cells or clones of QT6 cells at different times after transfection, and titers were then determined on equivalent populations of CEF or QT6 cells. The titrations were judged by the outgrowth of G418-resistant colonies and expressed as infectious $\mathrm{Neo}^{\mathrm{r}}$ units per milliliter of culture supernatant. The production of recombinant virus was greater than $10^{5}$ $\mathrm{Neo}^{r}$ units per $\mathrm{ml}$ by all $\mathrm{Neo}^{r}$-selected groups of cells, regardless of the cell type, helper virus, or SFCV provirus present, with the exception of RAV-1 transfectants (Table 2). In general, RAV-1-transfected cells produced lower levels of virus with any SFCV construct than did RAV-2- or RCAN-BHpol-transfected cells. In addition, virus production by QT6 cells (clones) tended to be more uneven than that by CEF (pools), which was not unexpected. The results also show that relatively high virus production $\left(1 \times 10^{4}\right.$ to 2 $\times 10^{4} \mathrm{Neo}^{\mathrm{r}}$ units per $\mathrm{ml}$ ) can be detected in unselected cells 
TABLE 2. Production of recombinant virus

\begin{tabular}{|c|c|c|c|c|}
\hline \multirow{2}{*}{ Provirus } & \multirow{2}{*}{ Cell type } & \multirow{2}{*}{ Helper } & \multicolumn{2}{|c|}{ Titer $\left(\mathrm{Neo}^{\mathrm{r}} \text { units } / \mathrm{ml}\right)^{a}$} \\
\hline & & & $48 \mathrm{~h}$ & G418 selected \\
\hline \multirow[t]{6}{*}{ SFCV-neo } & CEF & RAV-1 & $<1 \times 10^{3}$ & $4 \times 10^{6}$ \\
\hline & & RAV-2 & ND & $1 \times 10^{6}$ \\
\hline & & RCAN-BHpol & $2 \times 10^{4}$ & $5 \times 10^{6}$ \\
\hline & QT6 & RAV-1 & $>1 \times 10^{3}$ & $1 \times 10^{5}$ \\
\hline & & RAV-2 & $>1 \times 10^{3}$ & $1 \times 10^{6}-8 \times 10^{6}$ \\
\hline & & RCAN-BHpol & $1 \times 10^{4}$ & $5 \times 10^{6}$ \\
\hline \multirow[t]{2}{*}{ SFCV- $\beta$} & QT6 & RAV-1 & $<1 \times 10^{3}$ & $<1 \times 10^{3}$ \\
\hline & & RCAN-BHpol & $1 \times 10^{4}$ & $1 \times 10^{6}-10 \times 10^{6}$ \\
\hline SFCV-BIIIR & CEF & RCAN-BHpol & ND & $1 \times 10^{6}-8 \times 10^{6}$ \\
\hline SFCV-BIIIW & CEF & RCAN-BHpol & ND & $2 \times 10^{5}-10 \times 10^{5}$ \\
\hline SFCV-Blue ${ }^{b}$ & CEF & RCAN-BHpol & ND & $2 \times 10^{6}-4 \times 10^{6 c}$ \\
\hline
\end{tabular}

a Titers of less than $10^{3}$ were not scored. ND, Not done. Results are tabulated from several pSFCV variants and helper viruses. CEF titers are taken from pools of cells, and QT6 titers are averages of individual clones.

${ }^{b}$ Includes the percentage of cells scoring positive in situ $\beta-G a l$ assays.

c Of neo ${ }^{r}$ colonies, $>89 \%$ were $\beta-G a l$ positive.

harboring pSFCV-neo and RCAN-BHpol as early as $48 \mathrm{~h}$ posttransfection.

The production of virus by the SFCV-neo-transfected packaging lines Q2 and Q4 (Table 3) was lower than that by helper-cotransfected cells, which was expected. Half of the Q2 transfectants produced titers of between $10^{2}$ and $10^{3}$ infectious $\mathrm{Neo}^{\mathrm{r}}$ units per $\mathrm{ml}$, while the other half produced virus at levels too low to detect $\left(<20 \mathrm{Neo}^{\mathrm{r}}\right.$ units per $\left.\mathrm{ml}\right)$. The Q4 packaging line produced consistently higher titers of around $2 \times 10^{4} \mathrm{Neo}^{\mathrm{r}}$ units per ml, though again from only half of the clones selected. No recombinant helper virus was detected from any of the clones when the techniques described in Materials and Methods were used. However, when SFCV-neo-transfected Q2 or Q4 cells were maintained as uncloned pools of G418-resistant cells, even for short periods, recombinant helper could be detected in the medium of QT6 cells infected with culture supernatants from those pools. This meant that recombination of SFCV-neo with the resident RAV-1 genome of Q2 or Q4 cells was frequent enough to detect in any transfection but could be avoided by selection of individual clones of virus-producing cells.

Production of virus by pSFCV-Blue-transfected Isolde packaging cell pools or clones was consistently between $1 \times$ $10^{4}$ and $5 \times 10^{4} \mathrm{Neo}^{\mathrm{r}}$ units $^{\mathrm{e}}$ per $\mathrm{ml}$ of cell culture supernatant (Table 3). This was equal to those values observed with packaging line Q4. However, unlike the situation with $Q 2$ or Q4 transfectants, the presence of recombinant helper virus could not be detected (see Materials and Methods) in cloned or uncloned pools of Isolde transfectants. Of $22 \mathrm{Neo}^{\mathrm{r}}$ clones tested, all scored positive for $\beta$-Gal production, with 18 clones at least $90 \% \beta-\mathrm{Gal}$ positive. When assayed for virus production by dot blot, these 18 cloned lines all produced about $10^{4}$ virus units per $\mathrm{ml}$ (Table 3 ). A total of 80 to $85 \%$ of cells infected with these Isolde supernatants also scored positive by in situ $\beta-G a l$ assays.

Integration and maintenance of SFCV-neo provirus. To examine the status of the SFCV provirus, virus supernatants were used to infect CEF or QT6 cells, and Neo ${ }^{r}$ pools (CEF) or clones (QT6) of cells were isolated and expanded for Southern analysis. BstXI, which cuts in the retroviral LTRs, and $B g l \mathrm{II}$, which cuts once in SFCV, were used to determine integration sites and copy number, respectively, of the SFCV provirus in infected cells. The SFCV-neo provirus was integrated and stably maintained at one to three copies per cell in all cell populations (Fig. 2). The probe used for this purpose was a 910 -bp neo fragment. In some lanes $\left(\mathrm{SFCV}-\beta^{*}\right), 10 \mathrm{pg}(\sim 1$ copy equivalent) of pSFCV-neo plasmid DNA was included in the restriction digests for comparison. The first lane contains BstXI-cleaved pSFCVneo DNA alone.

Expression of $\beta$-Gal activity by pSFCV- $\beta$ and pSFCV-Blue. Transfected $\mathrm{Neo}^{r}$ populations of CEF cells expressing SFCV- $\beta$ were assayed in situ for $\beta-G a l$ activity. In general, 1 to $10 \%$ of the cells expressed enzyme activity, and clones of cells remained uneven, with a fraction losing or gaining

TABLE 3. Virus titers for transfected cell lines ${ }^{a}$

\begin{tabular}{|c|c|c|c|c|c|}
\hline Packaging line & $\begin{array}{c}\text { Transfecting } \\
\text { agent }\end{array}$ & Cell clones ${ }^{b}$ & Titer ${ }^{c}$ & $\begin{array}{l}\text { Presence } \\
\text { of helper }\end{array}$ & $\begin{array}{c}\beta \text {-Gal positive } \\
(\%)\end{array}$ \\
\hline \multirow[t]{3}{*}{ Q2 } & SFCV-neo & $1-4$ & $7 \times 10^{1}-8 \times 10^{2}$ & - & \\
\hline & & $5-10$ & $<1 \times 10^{1}$ & - & \\
\hline & & Pool & $2 \times 10^{2}$ & + & \\
\hline \multirow{3}{*}{ Q4 } & SFCV-neo & $1-5$ & $2 \times 10^{4}-5 \times 10^{4}$ & - & \\
\hline & & $6-10$ & $<1 \times 10^{1}$ & - & \\
\hline & & Pool & $3 \times 10^{4}$ & + & \\
\hline \multirow{3}{*}{ Isolde } & SFCV-Blue & $1-18$ & $2 \times 10^{4}-5 \times 10^{4 d}$ & - & $>90$ \\
\hline & & $19-22$ & $1 \times 10^{3}-5 \times 10^{3 d}$ & - & $20-50$ \\
\hline & & Pool & $1 \times 10^{4 d}$ & - & $>90$ \\
\hline
\end{tabular}

${ }^{a}$ Packaging cells were transfected with DNA from pSFCV variants, and individual $\mathrm{Neo}^{\mathrm{r}}$ clones were isolated and assayed for titer. The clones are grouped according to relative titers.

${ }^{b}$ Pools were of uncloned $\mathrm{Neo}^{\mathrm{r}}$ cells.

c Titers of less than $2 \times 10^{1}$ were not scored in this assay.

${ }^{d}$ Estimated virus titer from dot blot assays expressed as $\mathrm{Neo}^{\mathrm{r}}$ units ${ }^{\mathrm{e}}$ per milliliter. 


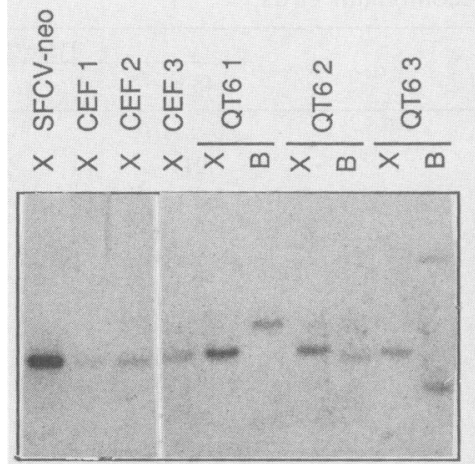

SFCV-neo
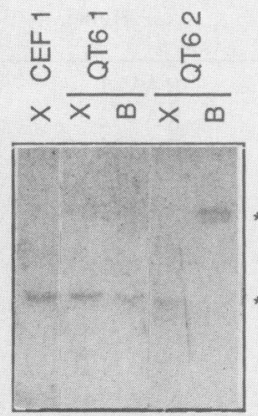

SFCV-BIIIR

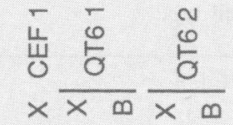

$\mathrm{kb}$

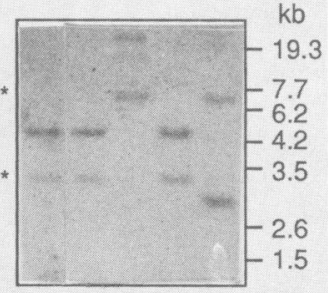

SFCV- $\beta$

FIG. 2. Southern blot of SFCV provirus in SFCV-neo- or SFCV-BIIIR-infected QT6 or CEF cells. High-molecular-weight DNA (10 $\mu$ g) from infected cells was cleaved with Bg/II (lanes B) to analyze integration sites or with BstXI (lanes X) to determine copy number of proviruses. SFCV-neo, DNA from SFCV-neo-infected pools of CEF cells (pools 1 to 3) or isolated clones of QT6 cells (clones 1 to 3); SFCV-BIIIR, DNA from SFCV-BIIIR-infected pools of CEF cells (pools 1 and 2) or isolated clones of QT6 cells (clones 1 and 2); SFCV- $\beta^{*}$, DNA from SFCV- $\beta$-infected pools of CEF cells (pool 1) or clones of QT6 cells (clones 1 and 2 ) along with 10 pg ( $\sim 1$ copy equivalent) of pSFCV-neo DNA as an internal control for comparison. The asterisks represent the migration of the pSFCV-neo internal plasmid controls in SFCV- $\beta^{*}$ lanes. Numbers on the right indicate the sizes of fragments of the StyI-cleaved $\lambda$ DNA marker. The first lane in panel SFCV-neo contains a pSFCV-neo plasmid control. The probe used for this purpose was a ${ }^{32} \mathrm{P}$-labeled 910 -bp neo fragment.

expression as the cells were passaged for short periods. In an attempt to remedy the failure of pSFCV- $\beta$ to efficiently express $\beta-G a l$ activity, the vector was modified as described above. The new version, pSFCV-Blue, was then assayed in two sets of experiments for its ability to transduce $\beta-G a l$ activity to transfected or infected cells (Tables 2 and 3). CEF or Isolde cells were transfected with pSFCV-Blue and plated sparsely enough to distinguish individual colonies following G418 selection. These were assayed in situ for $\beta-G a l$ production and later stained with gentian violet to count all Neor colonies. In two separate transfections, 106 of $117(90 \%)$ and 50 of $56(89 \%)$ of $\mathrm{Neo}^{\mathrm{r}} \mathrm{CEF}$ colonies were positive for $\beta-\mathrm{Gal}$ activity. Of 22 isolated Isolde clones, all were positive for $\beta-G a l$ activity, with 18 clones being $>90 \%$ positive. To assess the ability of SFCV-Blue viruses to transduce $\beta-\mathrm{Gal}$ activity, supernatants of the 18 transfected Isolde cell clones were used to infect fresh CEF cells. Of the clones tested, all infected CEF pools scored positive by in situ staining. About $90 \%$ of the infected cells in any pool were $\beta$-Gal positive. When these CEF infectants are grown sparsely to isolate colonies, $>80 \%$ of the $\mathrm{Neo}^{\mathrm{r}}$ colonies were $\beta$-Gal positive, depending on the virus stock. These results are in stark contrast to the weak $\beta-\mathrm{Gal}$ activity transduced by our previous construct, $\mathrm{pSFCV}-\beta$.

Expression of RNAs from SFCV-neo LTR. Northern analysis of SFCV-neo-infected CEF or QT6 cells was used to determine the relative amounts of SFCV genomic and spliced RNAs present in infected cells. A neo probe detected the full-length genomic RNA in the SFCV-neo- and SFCVBIIIR-infected cells (Fig. 3). An env-specific probe detected all RNAs of vector and helper virus origin. Cells containing SFCV-neo proviruses without inserts produced the $3.0-\mathrm{kb}$ full-length SFCV-neo transcript, but they all failed to produce the expected spliced transcript of $1.25 \mathrm{~kb}$. Instead, a $2-k b$ cryptically spliced RNA was observed. In cells harboring SFCV proviruses containing foreign sequences (Fig. 3, band 3), the relative amount of this cryptically spliced RNA was lower than in SFCV-neo-infected cells, but an additional cryptically spliced mRNA was seen at $1.8 \mathrm{~kb}$. In cells harboring the SFCV-BIIIR construct, the probe for band 3 detected mainly the 6.1-kb full-length RNA, the $4.35-\mathrm{kb}$ spliced subgenomic RNA, and the cryptic $1.8-\mathrm{kb}$ RNA. The
SFCV-neo 2-kb cryptic splice could result from the utilization of a potential cryptic acceptor site created at the gag-neo junction. The $1.8-\mathrm{kb}$ cryptic splice could result from splicing within the band 3 protein coding sequences. The presence of these alternatively spliced mRNAs did not seem to interfere with the production of sufficient neo to provide G418 resistance or the production of band 3 protein from the correctly spliced mRNA. Experiments to determine the origin of these cryptic splice points are currently under way as part of an attempt to eliminate the points from the SFCV constructs.

Expression of SFCV gag-neo protein. Immunoprecipitation of gag-related proteins from SFCV-BIII-infected cells (Fig. 4) showed two specific products. The pr76 ${ }^{\text {gag }}$ protein represents the precursor gag protein expressed by the helper virus, whereas the smaller gag polypeptide is the vectorderived gag-neo fusion protein of 55,000 $M_{\mathrm{r}}$. The observed size of the p55 gag-neo protein is in agreement with the estimated size of a 482-amino-acid gag-neo fusion protein of 53,000 daltons. Though the amount of $\mathrm{p} 55^{\text {gag-neo }}$ protein was low compared with that of pr76 $6^{g a g}$ of the helper virus, it was sufficient to provide $\mathrm{Neo}^{\mathrm{r}}$, even at concentrations of $3 \mathrm{mg}$ of G418 per $\mathrm{ml}$, which is necessary for the selection of erythroblast cultures (data not shown).

Band 3 protein expression from SFCV in fibroblasts. The cDNA encoding chicken erythrocyte band 3 protein was successfully expressed in fibroblasts using the pSFCV-neo vector. Immunoprecipitation of band 3 protein (Fig. 4) in CEF cells transfected with SFCV-BIIIR and RCAN-BHpol showed a strong band in the $95-\mathrm{kDa}$ molecular size range which is absent from SFCV-BIIIW (opposite orientation)transfected cells and similar to the band for the native protein immunoprecipitated from EGF receptor-transformed erythroblasts (33). This size is in agreement with the established molecular weights of erythrocyte band 3 polypeptides of 100,000 and 105,000 (doublet). The cDNA used to express band 3 protein in the SFCV-BIIIR construct represents only one of these two polypeptides, which are generated by alternative initiation and splicing of mRNAs $(34,35)$.

Indirect immunofluorescence of CEF expressing the SFCV-BIII constructs (Fig. 5A) using a band 3-specific monoclonal antibody showed a bright ring of fluorescence 


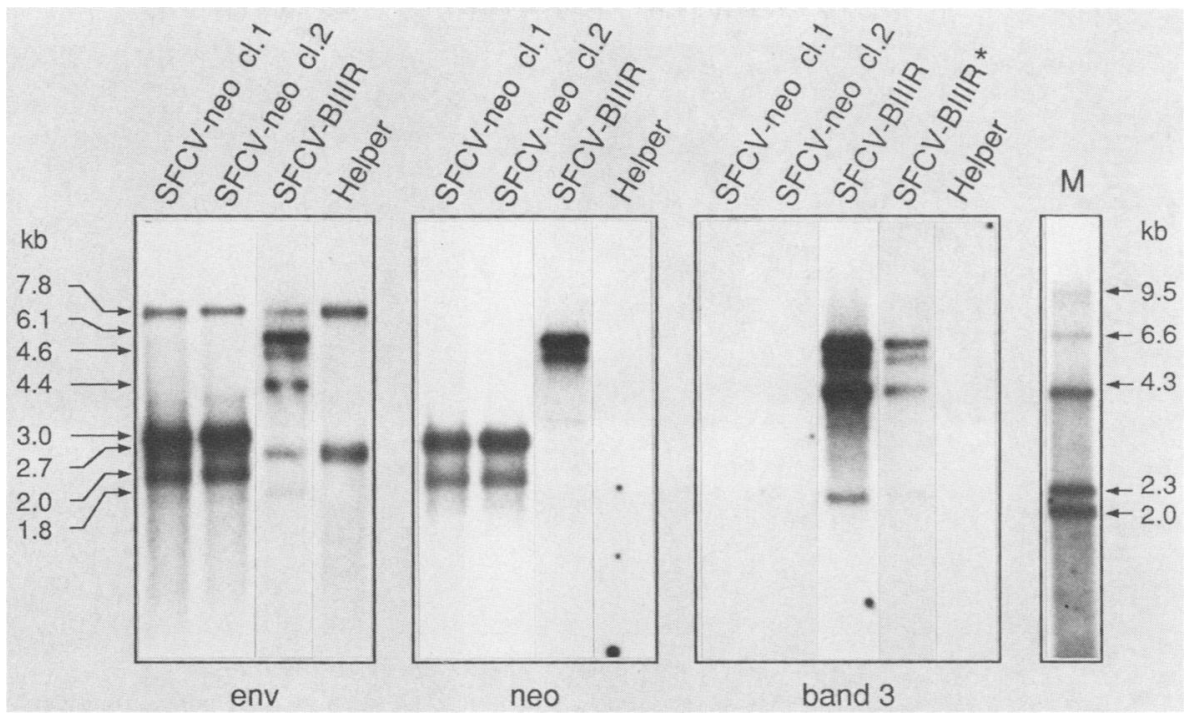

FIG. 3. Northern blot of RNAs expressed from SFCV proviruses in SFCV-neo- and SFCV-BIIIR-infected cells. Poly(A) ${ }^{+}$RNA $(2 \mu \mathrm{g})$ from SFCV-neo-infected QT6 cell clones (cl.), an SFCV-BIIIR-infected QT6 cell clone, or helper virus-infected QT6 cells was analyzed with a battery of probes. An env probe was used to detect all viral transcripts, a neo probe was used to detect SFCV-specific transcripts, or a chicken band 3 probe was used to detect band 3 transcripts. The marker (lane M) was an end-labeled HindIII-EcoRI digest of $\lambda$ DNA. The arrows on the left indicate the migration of the various RNAs: helper virus genomic and subgenomic transcripts, 7.8 and $2.7 \mathrm{~kb}$; SFCV-neo-derived genomic RNA, $3.0 \mathrm{~kb}$; cryptically spliced RNA, $2.0 \mathrm{~kb}$; band 3 protein-derived genomic RNA, 6.1 kb; subgenomic RNA, $4.4 \mathrm{~kb}$; cryptically spliced RNAs, 4.6 and $1.8 \mathrm{~kb}$. Lane SFCV-BIIIR* represents a shorter exposure of the SFCV-BIIIR lane to its left. The ${ }^{32} \mathrm{P}$-labeled probes used for this purpose were a 580-bp env fragment, a 910-bp neo fragment, and a 3.0-kb band 3 protein fragment, all derived from SFCV-BIIIR.

located at the periphery of cells transfected with SFCVBIIIR DNA and absent in SFCV-BIIIW counterparts. This is consistent with the plasma membrane localization of band 3 protein in erythrocytes and shows that the vector-encoded protein behaves in a manner consistent with its role in vivo. All $\mathrm{Neo}^{\mathrm{r}}$ clones or pools of band 3 protein-transfected or infected cells thus far analyzed have produced band 3 protein by one or more of the three criteria we use, i.e., immunoprecipitation, immunofluorescence, or vacuolization.

CEFs infected with SFCV-BIIIR, but not SFCV-BIIIW, viruses become highly vacuolated. In order to assess whether this was due to the ion exchange activity of the ectopically expressed band 3 protein, two experiments were performed. The first was to alter the bicarbonate content of the cell culture medium, which can be used to modulate anion transport activity. After $48 \mathrm{~h}$ in normal $\mathrm{pH} 7.2 \mathrm{me}-$ dium, the vacuoles remained (Fig. 5B), but when the same cells were grown in $\mathrm{pH} 8.0$ medium in a parallel experiment, the vacuoles disappeared. There was no change in SCFVBIIIW-transfected cells under the same conditions. All cells grew normally at both $\mathrm{pH}$ values.

Second, we used the compound DIDS (a stilbene disulfonate derivative), which functions as an inhibitor of band 3 protein by irreversibly binding to the extracellular domain of the protein and blocking anion transport. The addition of 0.4 mM DIDS to the cell culture medium caused, within $24 \mathrm{~h}$, the elimination of vacuoles from SFCV-BIIIR-transfected cells while having no apparent effect on their growth (Fig. 5C). There was no effect on SFCV-BIIIW-transfected cells under the same conditions (data not shown). These results also indicated that the ectopically expressed band 3 protein was located in the plasma membrane in the correct orientation and mediated anion transport, as does the endogenous erythrocyte protein. Each cell expressing the band 3 protein

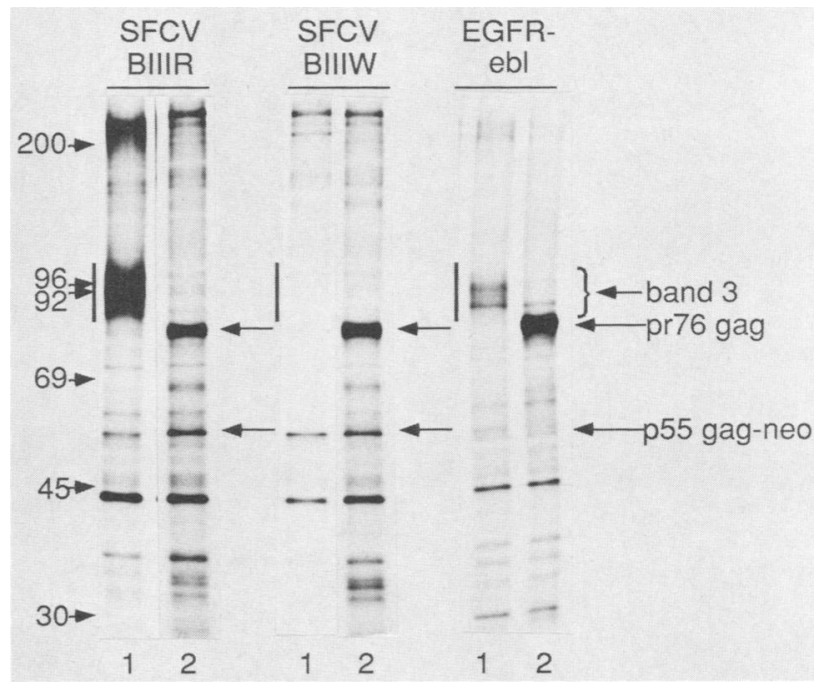

FIG. 4. Immunoprecipitation of p19 gag-related polypeptides or band 3 proteins from SFCV-BIIIR-infected cells. ${ }^{35}$ S-labeled proteins from infected cells were immunoprecipitated with anti-band 3 protein (lane 1) or anti-p19 ${ }^{\text {ag }}$ (lane 2) antibodies. The proteins were prepared from SFCV-BIIIR (left)- or SFCV-BIIIW (center)-infected CEF cells. The right-hand panel contains these proteins immunoprecipitated from human EGF receptor-transformed erythroblasts (EGFR-ebl). Arrows at the extreme right correspond to the anticipated migration of band 3- and p19gag -related proteins; pr76 gag, helper virus gag protein precursor; p55 gag-neo, gag-neo fusion protein encoded by SFCV-neo. The vertical bars to the left of lanes 1 represent the anticipated migration of band 3 polypeptides. The arrows to the right of lanes 2 indicate the anticipated migration of gag proteins. Numbers on the left correspond to the migration of molecular size standards in kilodaltons. 

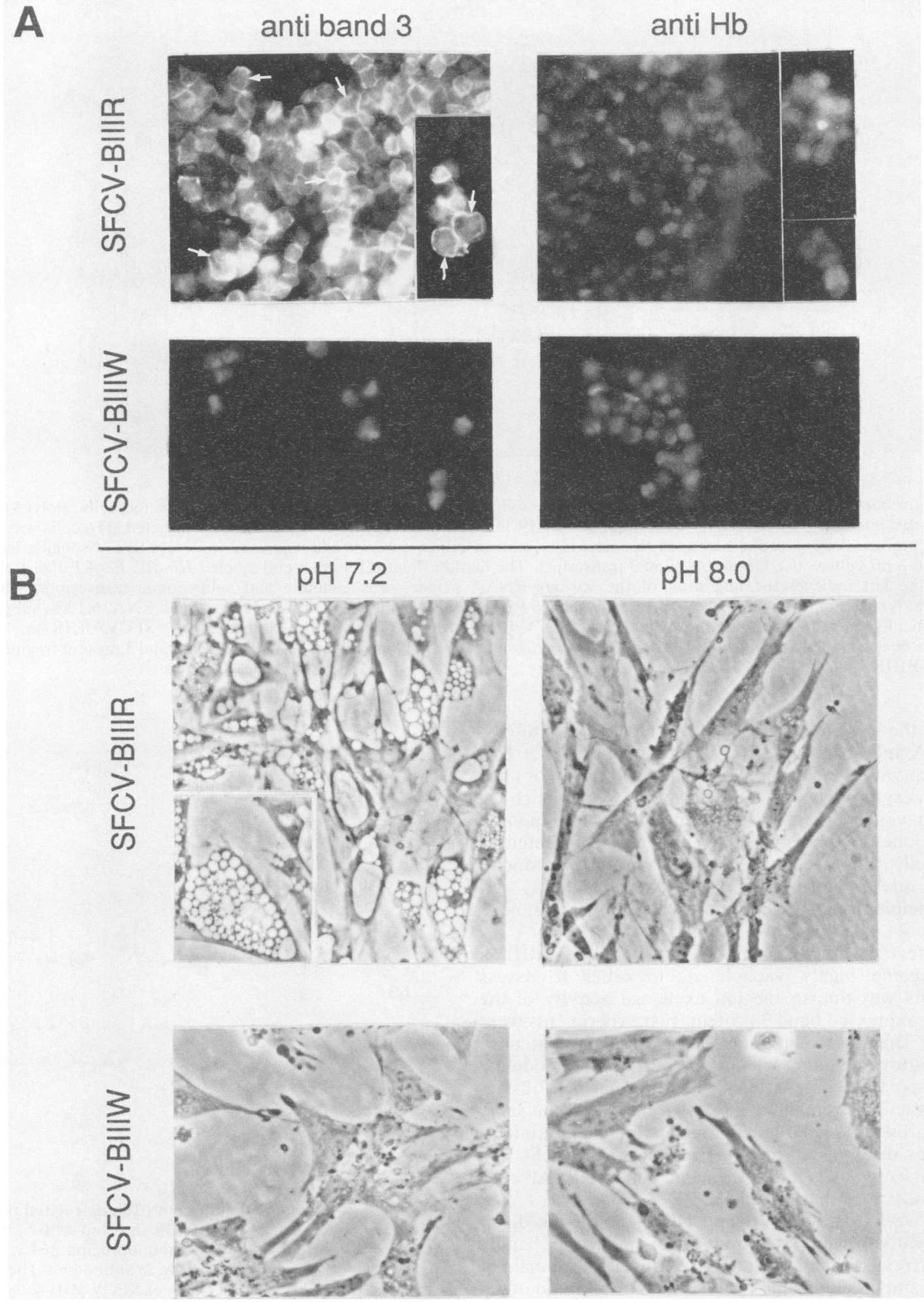

FIG. 5. (A) Band 3 protein-specific immunofluorescence of intact CEF cells containing SFCV-BIII proviruses. Indirect immunofluorescence of CEF cells expressing SFCV-BIIIR and SFCV-BIIIW proviruses. The left half of the panel shows cells stained for expression of band 3 protein, and the insert shows an enlargement of the same cells. The right half of the panel shows the same cells stained with antibodies to hemoglobin ( $\mathrm{Hb}$; negative control). Notice the intense peripheral staining of SFCV-BIIIR cells when the band 3 protein antibody is used (arrows). (B) Effect of pH on the vacuolization of SFCV-BIIIR-containing fibroblasts. The left half of the panel shows CEF cells grown for $48 \mathrm{~h}$ at the normal $\mathrm{pH}$ of 7.2. The right half of the panel shows the same pool of cells grown for $48 \mathrm{~h}$ in $\mathrm{pH} 8.0$ medium. Notice the multiple, large vacuoles in SFCV-BIII-containing cells at the normal $\mathrm{pH}$. (C) Effect of DIDS on band 3 protein-expressing fibroblasts. CEF cells harboring SFCV-BIIIR proviruses were cultivated for $24 \mathrm{~h}$ at $\mathrm{pH} 7.2$ in medium containing DIDS (right) (see Materials and Methods), an inhibitor ofband 3 protein ion exchange function. The figure on the left shows the same cells under normal conditions ( $\mathrm{pH} 7.2$, no DIDS). 


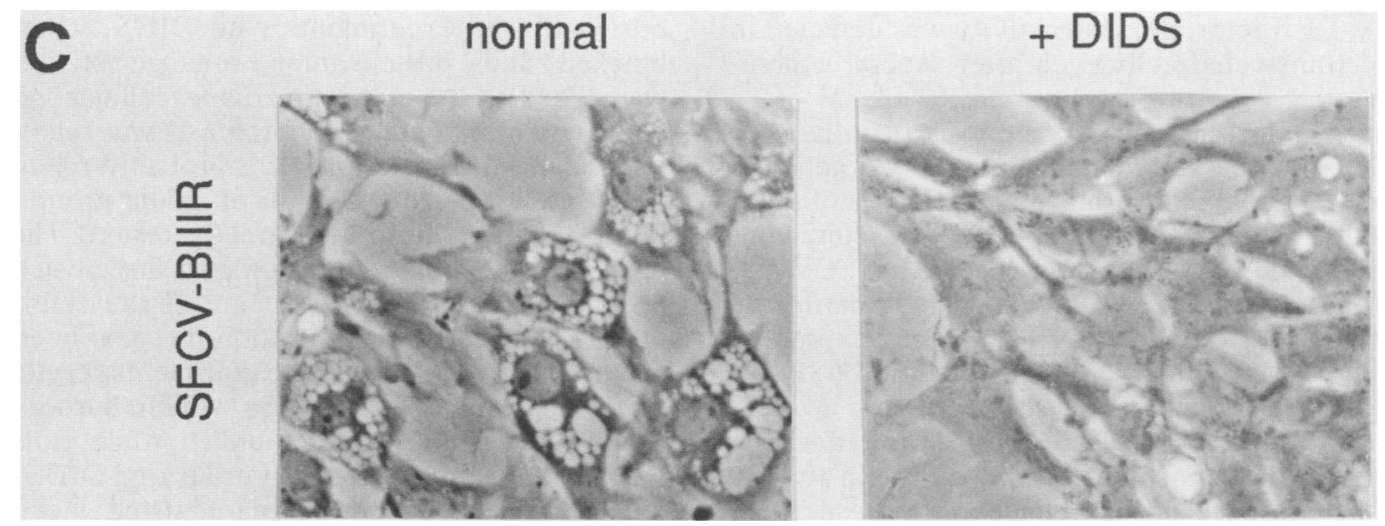

FIG. 5-Continued

acquired vacuoles, which served as an excellent visual marker for vector function in this cell type.

\section{DISCUSSION}

The SFCV-neo vector was adapted from AEV-ES4 with the object of retaining several features important for viral replication, such as the high activity of the viral LTRs in many types of avian cells and the ability of AEV to produce large amounts of virus with functions provided in trans by several different helper viruses. The LTRs contained the viral promoter, cap site, polyadenylation signals, proviral integration sites, and one of the important enhancer sequences, located in the R-U3 region $(38,54)$. In addition, several cis-acting elements outside of the viral LTRs were also retained, as discussed below.

Packaging sequences $(\psi)$ of the avian retroviruses are found at several points on the viral genomic RNA. An important $\psi$ sequence lies in the untranslated leader region between U5 and the start of gag (32). This $\sim 30$-bp sequence is located $\sim 250 \mathrm{bp}$ from the $5^{\prime}$ end of the genomic RNA and constitutes a major part of the sequences required for efficient encapsidation of viral RNAs; it overlaps in part with sequences affecting viral replication and protein translation $(5,46,49)$. In addition, another important packaging signal lies within the structural gene for gag (51), about $150 \mathrm{bp}$ downstream of the splice donor site. Also, some of the sequences directly involved in the genome dimerization step necessary for encapsidation are located in this region (5). Finally, noncoding sequences $3^{\prime}$ of env are thought to be involved in viral genome assembly $(27,58)$ for packaging. SFCV-neo was designed to encompass all of the sequences mentioned above.

In the avian sarcoma and leukosis viruses, other cis-acting sequences overlap the gag coding sequences, and they are retained in SFCV-neo. These sequences affect splicing (39, 57,61 ), contain determinants of viral tropism (53), and also make up a second important enhancer region $(1,8,61)$. Recent studies using in vitro chloramphenicol acetyltransferase assays show that a series of deletions in gag, extending from the $3^{\prime}$ end, result in a continual reduction in transcriptional activity compared with that of the intact sequence (1). In mutations extending beyond a critical region, transcription is markedly reduced. This enhancer region, required for efficient viral transcription in some cell types $(1,61)$, is located just upstream of the gag-neo junction in pSFCV-neo (nt 2243).

To avoid promoter interference by competing transcrip- tional regulatory domains (18), we chose to express inserted sequences from spliced, subgenomic RNAs in SFCV-neo. RSV efficiently utilizes multiple splice acceptors in this context (env and $s r c$ ). The splice donor site in SFCV is located after the sixth codon in gag, and the splice acceptor site is that of the v-erbB gene, both derived from AEV. In the context of SFCV, these sequences functioned efficiently to direct the splicing of subgenomic mRNAs when cloned inserts were present in the SFCV-neo polylinker. In the absence of cloned sequences, the expected subgenomic mRNA could not be detected, and cryptically spliced RNAs were present in all SFCV-neo variants. These cryptic splices probably result from the introduction of foreign sequences, such as neo, into the retroviral genome and do not seem to interfere with splicing or translation of the correct mRNAs in pSFCV-transfected or infected cells. Cryptic splicing has also been noted in murine retrovirus vectors $(7$; personal communication); the aberrant splicing seems to have no effect on expression of correctly spliced RNAs. However, experiments are currently under way to determine the sites of these aberrant splice points and remove them from pSFCV.

The SFCV polylinker is immediately downstream of the SFCV splice acceptor and contains first a stop codon, closing the reading frame initiated in the RNA leader; then restriction sites for $H i n d I I I, E c o R V, B g l \mathrm{I}, S f i \mathrm{I}, C l a \mathrm{I}, X b a \mathrm{I}$, and EcoRI; and then stop codons in all frames. By using adaptor plasmids which carry the RSV src splice acceptor, leader sequence, and an adjoining polylinker on a ClaI fragment (25), a second spliced mRNA could potentially be produced by SFCV-neo proviruses.

In pSFCV-LE, a further modification has been made in the region near the splice acceptor. We have inserted a modified, synthetic 88-bp human EGF receptor fragment (nt 105 to 186) to provide a spacer between the stop codon and the beginning of the polylinker. This sequence, in an unmodified form, has been previously used by our lab to produce about $10^{6}$ EGF receptor molecules per cell from an AEV vector in a similar context (33). It has been shown that a minimum sequence is required between a stop codon and an in-frame AUG to allow efficient ribosomal reinitiation (37). The original SFCV- $\beta-$ Gal construct (SFCV- $\beta$ ) was a $3.3-\mathrm{kb}$ fragment cloned into the first (HindIII) site of the polylinker. SFCV- $\beta$ produced weak, erratic $\beta-G a l$ activity in transfected

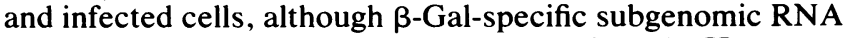
was abundant in these cells (data not shown). However, when the $\beta-G a l$ gene was cloned into the HindIII site of the 
modified SFCV-LE vector, enzyme activity was detected in $>90 \%$ of $\mathrm{Neo}^{\mathrm{r}}$ transfected cells even after several generations in culture.

The potential cloning capacity of SFCV-neo can be estimated from RSV. This virus encodes a 9.3-kb genomic RNA, and infectious mutants with a genome length of up to $10.1 \mathrm{~kb}$ exist (48). This would allow, by analogy, cloning of between 6.4 and $7 \mathrm{~kb}$ of foreign sequence into SFCV-neo without impairing the efficiency of packaging. Experiments to test this are currently under way: two genes expressed from separate splice acceptors will be inserted into pSFCVLE. The total insert size will be $6.5 \mathrm{~kb}$.

The fusion of gag to neo in SFCV-neo did not affect the ability of the neomycin phosphotransferase protein to provide $\mathrm{Neo}^{\mathrm{r}}$ in the presence of high concentrations of G418, and the cis- and trans-acting activities present in gag appeared to be undisturbed. Consequently, all of the important regulatory signals encoding splicing, enhancer, and $\psi$ sequences were retained in the gag region, while the neo portion efficiently provided G418 resistance to infected cells, as shown by titration experiments. In SFCV-neo, both the unspliced and the spliced mRNAs were efficiently translated into protein, as shown by immunoprecipitation of the gag neo and band 3 proteins.

We have used the $E$. coli lacZ ( $\beta-\mathrm{Gal})$ gene to test the features of vector function. Using two separate $\beta-G a l$ constructs, we have tested expression of $\beta-\mathrm{Gal}$ protein by in situ analysis and analyzed virus titers from SFCV- $\beta$-gal-transfected cells. Using the SFCV-Blue construct in transfection experiments with both QT6 and CEF cells, we have shown that enzyme activity is efficiently expressed in $>90 \%$ of G418-selected clones or pools of cells. When supernatants from three of these cell clones were used to infect CEF cells, $>80 \%$ of colonies were $\beta-G a l$ positive $\mathrm{Neo}^{\mathrm{r}}$. SFCV-Blue has also been used to express $\beta-\mathrm{Gal}$ in erythroblasts (data not shown), and $>95 \%$ of the infected $\mathrm{Neo}^{\mathrm{r}}$ erythroblasts expressed enzyme activity by in situ analysis. SFCV- $\beta$ RCAN-BHpol-cotransfected QT6 cells efficiently produced $10^{6} \mathrm{Neo}^{r}$ units per ml of virus, and SFCV-Blue-RCANBHpol-cotransfected CEF cells yielded similar titers of $2 \times$ $10^{6}$ to $4 \times 10^{6} \mathrm{Neo}^{\mathrm{r}}$ units per ml.

We chose the cDNA for the erythrocyte anion transporter to analyze the expression of a eucaryotic gene from the SFCV-neo vector. We are also interested in the role of band 3 protein repression by $\mathrm{v}-\mathrm{erbA}$ in the $\mathrm{AEV}$ transformation of erythroblasts (68). The SFCV viruses are intended for use in erythroblasts as well as fibroblasts, and it was anticipated that the ectopic expression of band 3 protein in fibroblasts could be readily monitored. The expression of the anion transporter protein from the SFCV-BIIIR provirus, in fact, caused vacuolization of the infected fibroblasts. Recently published data from studies using a neuronal homolog of murine band 3 protein expressed in COS cells (36) showed that ectopic anion transporter expression caused intracellular acidification. This was also seen when murine erythroid band 3 protein was expressed in Xenopus oocytes (2). Thus, under normal culture conditions, the anion transporter exchanges intracellular $\mathrm{HCO}_{3}^{-}$for extracellular $\mathrm{Cl}^{-}$in a manner dependent on the bicarbonate and chloride content of the medium. In fibroblasts infected with SFCV-BIIIR viruses, vacuolization was presumably due to intracellular acidification, since this phenotype could be abolished by growing the cells in alkaline medium. An interpretation of this is that the addition of extra bicarbonate to increase the $\mathrm{pH}$ of the medium altered the anion exchange activity, thereby relieving the vacuolization. This hypothesis is sup- ported by the experiments with DIDS, which irreversibly blocked band 3 protein anion exchange activity. When DIDS was added to the culture medium, cellular vacuolization in band 3 protein-containing fibroblasts was relieved. Effects of intracellular acidification were probably relieved in SFCVBIIIR cells by sequestration of acidic groups in vacuoles, though this has not been directly tested. The presence of band 3 protein and the multiple, large vacuoles did not appear to affect the growth rate of the cells. This band 3 protein-associated vacuolization has also been reported for erythroblasts (68). In these experiments, erythroblasts were infected with an AEV virus which harbors a defective $\mathrm{v}$-erbA; the cells were vacuolated when cultivated in medium of the inappropriate $\mathrm{pH}$ or lacking DIDS, whereas this phenotype was absent in $\mathrm{pH}$-adjusted medium. Furthermore, the vacuolization in erythroblasts could be abolished by expression of the normal v-erbA oncogene, which completely repressed band 3 protein gene expression.

The phenotype induced by the ectopic expression of band 3 protein activity at the plasma membrane of infected fibroblasts provided a visual marker for the correct transcription, translation, transport, and stability of sequences transduced by SFCV-neo. Though the band 3 anion exchange protein is encoded by two polypeptides in avian cells, we have shown that the expression of one of these proteins is sufficient for the proper transport, plasma membrane localization, and expression of anion exchange activity in SFCV-BIIIR-infected CEFs. We estimate that the amount of band 3 protein expressed in these fibroblasts is similar to the abundance of native band 3 in mature erythrocytes (data not shown), judged by immunoprecipitation experiments.

\section{ACKNOWLEDGMENTS}

We thank Steve Hughes for supplying the RCAN-BHpol plasmid and for valuable discussions. We thank the laboratory of Mina Bissel for supplying the Q2 and Q4 packaging cells and FrançoisLoic Cosset for the Isolde packaging line. We thank Douglas Forrest and Gösta Winberg for critical reading of the manuscript. We also thank Kristina Nordström for excellent technical assistance and Gunnel Jönsson for help with the preparation of the manuscript. The support of the European Molecular Biology Laboratory during the initial phases of this work is acknowledged.

S.F. was supported by the Swedish Medical Research Foundation, and A.M. was supported by the Juan March Foundation. Grants were obtained from the Swedish Cancer Society, the Wallenberg Foundation, the Children's Cancer Fund, and Kjell and Märta Beijer's Foundation.

\section{LITERATURE CITED}

1. Arrigo, S., M. Yun, and K. Beemon. 1987. cis-Acting regulatory elements within gag genes of avian retroviruses. Mol. Cell. Biol. 7:388-397.

2. Bartel, D., S. Lepke, G. Layh-Schmitt, B. Legrum, and $H$. Passow. 1989. Anion transport in oocytes of Xenopus laevis induced by expression of mouse erythroid band 3 proteinencoding cRNA and of a cRNA derivative obtained by sitedirected mutagenesis at the stilbene disulfonate binding site. EMBO J. 8:3601-3609.

3. Beug, H., T. Graf, and M. J. Hayman. 1981. Production and characterization of antisera specific for the erbB portion of $\mathrm{p} 75$, the presumptive transforming protein of avian erythroblastosis virus. Virology 111:201-210.

4. Beug, H., A. von Kirchbach, G. Döderlein, J. F. Conscience, and T. Graf. 1979. Chicken hematopoetic cells transformed by seven strains of defective avian leukemia viruses display three distinct phenotypes of differentiation. Cell 18:375-390.

5. Bieth, E., C. Gabus, and J.-L. Darlix. 1990. A study of the dimer formation of Rous sarcoma virus RNA and of its effect on viral 
protein synthesis in vitro. Nucleic Acids Res. 18:119-127.

6. Bosselman, R. A., R.-Y. Hsu, T. Boggs, S. Hu, J. Bruszewski, S. Ou, L. Souza, L. Kozar, F. Martin, M. Nicolson, W. Rishell, J. A. Schultz, K. M. Semon, and R. G. Stewart. 1989. Replication-defective vectors of reticuloendotheliosis virus transduce exogenous genes into somatic stem cells of the unincubated chicken embryo. J. Virol. 63:2680-2689.

7. Boulter, C. A., and E. F. Wagner. 1987. A universal retrovirus vector for efficient constitutive expression of exogenous genes. Nucleic Acids Res. 15:7194.

8. Carlberg, K., T. A. Ryden, and K. Beemon. 1988. Localization and footprinting of an enhancer within the avian sarcoma virus gag gene. J. Virol. 62:1617-1624.

9. Cepko, C. L., B. E. Roberts, and R. C. Mulligan. 1984. Construction of a highly transmissible murine retrovirus shuttle vector. Cell 37:1053-1062.

10. Chen, C., and H. Okayama. 1987. High-efficiency transformation of mammalian cells by plasmid DNA. Mol. Cell. Biol. 7:2745-2752.

11. Coffin, J. 1985. Genome structure, p. 17-43. In R. Weiss, N. Teich, A. Varmus, and J. Coffin (ed.), Molecular biology of tumor viruses, part III, vol. 2. Cold Spring Harbor Laboratory, Cold Spring Harbor, N.Y.

12. Cone, R. D., and R. C. Mulligan. 1984. High efficiency gene transfer into mammalian cells: generation of helper-free recombinant retrovirus with broad mammalian host range. Proc. Natl. Acad. Sci. USA 81:6349-6353.

13. Cosset, F.-L., C. Legras, Y. Chebloune, P. Savatier, P. Thoraval, J. L. Thomas, J. Samarut, V. M. Nigon, and G. Verdier. 1990. A new avian leukosis virus packaging cell line that uses two separate transcomplementing helper genomes. J. Virol. 64: 1070-1078.

14. Damm, K., H. Beug, T. Graf, and B. Vennström. 1987. A single point mutation in erbA restores the erythroid transforming potential of a mutant avian erythroblastosis virus (AEV) defective in both erbA and erbB oncogenes. EMBO J. 6:375-382.

15. Dannenberg, A. M., and M. Suga. 1981. In D. O. Adams, P. J. Edelson, and M. S. Koren (ed.), Methods for studying mononuclear phagocytes, p. 375-396. Academic Press, Inc., N.Y.

16. Dougherty, J. P., R. Wisniewski, S. Yang, B. W. Rhode, and H. M. Temin. 1989. New retrovirus helper cells with almost no nucleotide sequence homology to retrovirus vectors. J. Virol. 63:3209-3212.

17. Eglitis, M. A., and W. F. Andersen. 1988. Retroviral vectors: introduction of genes into mammalian cells. BioTechniques 6:608-614

18. Emmerman, M., and H. M. Temin. 1984. Genes with promoters in retrovirus vectors can be independently suppressed by an epigenetic mechanism. Cell 39:459-467.

19. Feinberg, A. P., and V. Vogelstein. 1984. A technique for radio-labeling DNA restriction endonuclease fragments to a high specific activity. Anal. Biochem. 137:266-267.

20. Freundenstein, C., H. Beug, S. Palmieri, and T. Graf. 1982. Expression of embryonic haemoglobin in ts AEV-transformed embryonic eythroid cells during temperature-induced differentiation. Differentiation 22:231-234.

21. Frykberg, L., S. Palmeri, H. Beug, T. Graf, M. J. Hayman, and B. Vennström. 1983. Transforming capacities of avian erythroblastosis virus mutants deleted in the erbA or erbB oncogenes. Cell 32:227-238.

22. Graf, T. 1973. Two types of target cells for transformation with avian myelocytomatosis virus. Virology 54:398-413.

23. Graf, T., and H. Beug. 1978. Avian leukemia viruses: interaction with their target cells in vitro. Biochim. Biophys. Acta 516:269-299.

24. Graham, F. L., and A. J. Van der Eb. 1973. Transformation of rat cells by DNA of human adenoviruses. Virology 52:456-467.

25. Hayman, M. J., H. Beug, and K. Savin. 1982. Changes in the expression of membrane antigens during the differentiation of erythroid precursor cells. J. Cell. Biochem. 18:351-362.

26. Hayman, M. J., B. Royer-Pokora, and T. Graf. 1979. Defectiveness of avian erythroblastosis virus: synthesis of a $75 \mathrm{~K} \mathrm{gag}$ related protein. Virology 92:31-45.
27. Hirano, A., and T. C. Wong. 1989. Mutations in the 3 '-untranslated region of avian sarcoma virus LA46 genome confer the cis-acting temperature sensitive defect. Virology 172:651-654.

28. Hughes, S. H., J. J. Greenhouse, C. J. Petropoulos, and P. Sutrave. 1987. Adaptor plasmids simplify the insertion of foreign DNA into helper-independent retroviral vectors. J. Virol. 61: 3004-3012.

29. Hughes, S. H., and E. Kosik. 1984. Mutagenesis at the region between env and src of the SR-A strain of Rous sarcoma virus for the purpose of constructing helper-independent vectors. Virology 136:89-99.

30. Jay, D. G. 1983. Characterization of the chicken erythrocyte anion exchange protein. J. Biol. Chem. 258:9431-9436.

31. Kantoff, P., A. P. Guillo, J. R. Melachlin, C. Bordignon, M. A. Eglitis, N. A. Kernom, R. C. Moln, D. R. Kohn, S. F. Yu, E. Karson, S. Karlsson, J. A. Zwiebel, E. Gilboa, R. M. Blaese, A. Neinhuis, R. J. O'Reilly, and W. F. Anderson. 1987. Expression of human adenosine deaminase in nonhuman primates after retrovirus-mediated gene transfer. J. Exp. Med. 166:219-239.

32. Katz, R. A., R. W. Terry, and A. M. Skalka. 1986. A conserved cis-acting sequence in the 5 ' leader of avian sarcoma virus RNA is required for packaging. J. Virol. 59:163-167.

33. Khazaie, K., T. J. Dull, T. Graf, J. Schlessinger, A. Ullrich, and B. Vennström. 1988. Truncation of the human EGF-receptor leads to differential transforming potentials in primary avian fibroblasts and erythroblasts. EMBO J. 7:3061-3071.

34. Kim, H.-R. C., B. S. Kennedy, and J. D. Engel. 1989. Two chicken erythrocyte band 3 mRNAs are generated by alternative transcriptional initiation and splicing. Mol. Cell. Biol. 9:5198-5206.

35. Kim, H.-R. C., N. W. Yew, W. Ansorge, H. Voss, C. Schwager, B. Vennström, M. Zenke, and J. D. Engel. 1988. Two different mRNAs are transcribed from a single genomic locus encoding the chicken erythrocyte anion transport proteins (band 3). Mol. Cell. Biol. 8:4416-4424.

36. Kopito, R. R., B. S. Lee, D. M. Simmons, A. E. Lindsey, C. W. Morgans, and K. Schneider. 1988. Regulation of intracellular $\mathrm{pH}$ by a neuronal homolog of the erythrocyte anion exchanger. Cell 59:927-937.

37. Kozak, M. 1987. Effects of intercistronic length on the efficiency of reinitiation by eucaryotic ribosomes. Mol. Cell. Biol. 7:34383445 .

38. Laiming, L. A., P. Tsichlis, and G. Khoury. 1984. Multiple enhancer domains in the 3' terminus of the Prague strain of Rous sarcoma virus. Nucleic Acids Res. 12:6427-6442.

39. Levantis, P., D. A. F. Gillespe, K. Hart, M. J. Bissel, and J. A. Wyke. 1986. Control of expression of an integrated Rous sarcoma provirus in rat cells: role of $5^{\prime}$ genomic duplications reveals unexpected patterns of gene transcription and its regulation. J. Virol. 57:907-916.

40. Maniatis, T., E. Fritsch, and J. Sambrook. 1982. Molecular cloning: a laboratory manual. Cold Spring Harbor Laboratory, Cold Spring Harbor, N.Y.

41. Markovitz, D., S. Goff, and A. Bank. 1988. A safe packaging line for gene transfer: separating viral genes on two different plasmids. J. Virol. 62:1120-1124.

42. Miller, A. D., M.-F. Law, and I. M. Verma. 1985. Generation of helper-free amphotropic retroviruses that transduce a dominantacting, methotrexate-resistant dihydrofolate reductase gene. Mol. Cell. Biol. 5:431-437.

43. Miller, C. K., and H. M. Temin. 1986. Insertion of several different DNAs in reticuloendotheliosis virus strain $T$ suppresses transformation by reducing the amount of subgenomic mRNA. J. Virol. 58:75-80.

44. Moscovici, C., M. G. Moscovici, H. Jimenez, M. M. C. Lai, M. J. Hayman, and R. K. Vogt. 1977. Continuous tissue culture cell line derived from chemically induced tumors of Japanese quail. Cell 11:95-103.

45. Mulligan, R., and P. Berg. 1981. Expression of a bacterial gene in mammalian cells. Science 209:1422-1425.

46. Murti, K. G., M. Bondurant, and A. Tereba. 1981. Secondary structural features in the 70S RNAs of Moloney murine leukemia and Rous sarcoma viruses as observed by electron micros- 
copy. J. Virol. 37:411-419.

47. Nemeth, S. P., L. G. Fox, M. DeMarco, and J. S. Brugge. 1989. Deletions within the amino-terminal half of the c-src gene product that alter the functional activity of the protein. Mol. Cell. Biol. 9:1109-1119.

48. Norton, P. A., and J. M. Coffin. 1985. Bacterial $\beta$-galactosidase as a marker of Rous sarcoma virus gene expression and replication. Mol. Cell. Biol. 5:281-290.

49. Peterson, R. B., A. Moustakas, and P. B. Hackett. 1989. A mutation in the short $5^{\prime}$-proximal open reading frame on Rous sarcoma virus alters virus production. J. Virol. 63:4787-4796.

50. Price, J., D. Turner, and C. Cepko. 1987. Lineage analysis in the vertebrate nervous system by retrovirus-mediated gene transfer. Proc. Natl. Acad. Sci. USA 84:156-160.

51. Pugatsch, T., and D. W. Stacey. 1982. Analysis by microinjection of the biological effects of site-directed mutagenesis in cloned avian leukosis viral DNAs. J. Virol. 43:503-510.

52. Robertson, E., A. Bradley, M. Kuehn, and M. Evans. 1986 Germ line transmission of genes introduced into cultured pluripotential cells by retroviral infection. Nature (London) 323:445448.

53. Robinson, H. L., S. S. Reinsch, and P. R. Shank. 1986. Sequences near the $5^{\prime}$ long terminal repeat of avian leukosis viruses determine the ability to induce osteopetrosis. J. Virol. 59:45-49.

54. Ruddell, A., M. L. Linial, and M. Groudine. 1989. Tissuespecific lability and expression of avian leukosis virus long terminal repeat enhancer-binding proteins. Mol. Cell. Biol. 9:5660-5668.

55. Salter, D. W., E. J. Smith, S. H. Hughes, S. E. Wright, and L. B. Crittenden. 1987. Transgenic chickens: insertion of retroviral genes into the chicken germ line. Virology 157:236-240.

56. Savatier, P., C. Bagnis, P. Thoraval, D. Poncet, M. Belakebi, F. Mallet, C. Legras, F.-L. Cosset, J.-L. Thomas, Y. Chebloune, C. Faure, G. Verdier, J. Samarut, and V. Nigon. 1989. Generation of a helper cell line for packaging avian leukosis virus-based vectors. J. Virol. 63:513-522.

57. Schirm, S., G. Moscovici, and J. M. Bishop. 1990. A temperature-sensitive phenotype of avian myeloblastosis virus: determinants that influence the production of viral mRNAs. J. Virol.
64:767-773.

58. Sorge, J., W. Ricci, and S. H. Hughes. 1983. cis-Acting RNA packaging locus in the 115-nucleotide direct repeat of Rous sarcoma virus. J. Virol. 48:667-675.

59. Stacey, D. W., J. J. Kopchick, and M. Kahn. 1986. The effects of transcriptional regulatory sequences introduced into a retroviral genome. DNA 5:195-202.

60. Stoker, A. W., and M. J. Bissell. 1988. Development of avian sarcoma and leukosis virus-based vector-packaging cell lines. J. Virol. 62:1008-1015.

61. Stoltzfus, C. M., L.-J. Chang, T. P. Cripe, and L. P. Turek. 1987. Efficient transformation by Prague A Rous sarcoma virus plasmid DNA requires the presence of cis-acting regions within the gag gene. J. Virol. 61:3401-3409.

62. Sudol, M., T. L. Lerner, and H. Hanafusa. 1986. Polymerasedefective mutant of the Bryan high-titer strain of Rous sarcoma virus. Nucleic Acids Res. 14:2391-2405.

63. Temin, H. M. 1986. Retrovirus vectors for gene transfer: efficient integration into and expression of exogenous DNA in vertebrate cell genomes, p. 149-187. In R. Kutherlapati (ed.), Gene transfer. Plenum Publishing Corp., New York.

64. Thoraval, P., P. Savatier, J.-H. Xiao, F. Mallet, J. Samarut, G. Verdier, and V. Nigon. 1988. Partial nucleotide sequence of the avian erythroblastosis virus (AEV-ES4). Nucleic Acids Res. 15:9612-9616.

65. Vennström, B., and M. Bishop. 1982. Isolation and characterization of chicken DNA homologous to the two putative oncogenes of avian erythroblastosis virus. Cell 28:135-143.

66. Vennström, B., L. Fanshier, and J. M. Bishop. 1980. Molecular cloning of the avian erythroblastosis virus genome and recovery of transforming virus using a chicken cell transfection assay. $\mathrm{J}$. Virol. 36:575-585.

67. Yew, N. S., H.-R. Choi, J. C. Gallarda, and J. D. Engel. 1987. Expression of cytoskeletal protein 4.1 during avian erythroid cellular maturation. Proc. Natl. Acad. Sci. USA 84:1035-1039.

68. Zenke, M., P. Kahn, C. Disela, B. Vennström, A. Leutz, K. Keegan, M. Hayman, H.-R. Choi, N. Yew, D. Engel, and H. Beug. 1988. V-erbA specifically suppresses transcription of the avian erythrocyte anion transporter gene. Cell 52:107-119. 